\title{
SEPTOHIPPOCAMPAL CHOLINERGIC NEURONS ARE REGULATED TRANS-SYNAPTICALLY BY ENDORPHIN AND CORTICOTROPIN NEUROPEPTIDES ${ }^{1}$
}

\author{
LAWRENCE J. BOTTICELLI ${ }^{2}$ AND RICHARD J. WURTMAN ${ }^{3}$
}

Laboratory of Neuroendocrine Regulation, Massachusetts Instilule of Technology, Cambridge, Massachusetts 02139

Received November 10, 1981; Revised February 25, 1982; Accepted April 7, 1982

\begin{abstract}
The content of acetylcholine ( $\mathrm{ACh})$ in nerve terminals or the dorsal hippocampus was examined after intraventricular, intraseptal, or intrahippocampal administration of a variety of endorphin/ corticotropin neuropeptides. $\beta$-Lipotropin, $\alpha$-endorphin, $\gamma$-endorphin, $\alpha$-melanotropin, $\beta$-melanotropin, adrenocorticotropin-1-39 $\left(\mathrm{ACTH}_{1-39}\right)$, and $\mathrm{ACTH}_{4-10}(1,3,10$, or $30 \mu \mathrm{g}$ each) did not affect levels of $\mathrm{ACh}$ in the hippocampus $30 \mathrm{~min}$ after injection into the lateral ventricle. $\beta$-Endorphin, administered intraventricularly $(1,3,10$, or $30 \mu \mathrm{g})$ or intraseptally $(1 \mu \mathrm{g})$, increased levels of $\mathrm{ACh}$, while $\mathrm{ACTH}_{1-24}$, injected similarly, decreased levels of the neurotransmitter. ACh concentrations remained unchanged after direct application of $\beta$-endorphin or $\mathrm{ACTH}_{1-24}(1,3,10$, or $30 \mu \mathrm{g}$ each) into Ammon's horn.

Acute unilateral transection of the fimbria/superior fornix resulted in a time-related decrease in hippocampal ACh concentrations. Levels of ACh did not change $1 \mathrm{hr}$ after transection; however, concentrations of hippocampal ACh decreased significantly $1 \mathrm{~d}$ or 1 week after deafferentation. ACh levels in the contralateral hippocampus remained unaffected at all times tested. Fimbrial transection blocked fully both endorphin- and corticotropin-induced changes in hippocampal ACh after the neuropeptides were injected into the lateral ventricle or the septal region.

Naloxone, which, after subcutaneous $(1 \mathrm{mg} / \mathrm{kg})$ or intraventricular $(100 \mu \mathrm{g})$ injection alone, failed to change levels of hippocampal $\mathrm{ACh}$, antagonized the effects of intraventricular or intraseptal $\beta$ endorphin or $\mathrm{ACTH}_{1-24}$ or hippocampal ACh levels.

The results suggest a site of endorphin/corticotropin receptor interaction at the level of cholinergic cell bodies in the septal region for regulating the activity of septohippocampal cholinergic neurons.
\end{abstract}

The septohippocampal cholinergic pathway is regulated by trans-synaptic mechanisms at the level of cholinergic cell bodies and dendrites in the septal region. Several lines of evidence suggest that a variety of neurochemical systems are operative in modulating the ac-

\footnotetext{
' 'T'hese studies were supported in part by research grants awarded to R. J. W. from the National Institute of Mental Health (MH 28783), the Center for Brain Sciences and Metabolism Charitable Trust, and the Wallace Genetic Foundation. We profited particularly from helpful discussions with Drs. Erminio Costa, Peter Dews, and John Fernstrom.

${ }^{2}$ Recipient of National Institute of Drug Abuse Predoctoral Fellowship Aware DA 05089. The data presented in this paper are taken in major part from a dissertation submitted by L. J. B. to the Program in Neural and Endocrine Regulation at the Massachusetts Institute of Technology, Cambridge, MA 02139. Present address: Department of Psychiatry and Behavioral Sciences, Stanford University School of Medicine, Stanford, CA 94305.

${ }^{3}$ To whom correspondence should be addressed at Room E25-604, Laboratory of Neuroendocrine Regulation, Massachusetts Institute of Technology, Cambridge, MA 02139.
}

tivity of this group of neurons. These include intrinsic $\gamma$-aminobutyric-acid-containing neurons (McLennan and Miller, 1974; DeFrance et al., 1975), dopamine afferents emanating from the ventral tegmentum (Assaf and Miller, 1977; Moore, 1978), noradrenergic neurons from the locus coeruleus and caudal brainstem (Moore, 1978), as well as substance $\mathrm{P}$ afferents arising from the medial basal hypothalamus (Cuello and Kanazawa, 1978; Malthe-Sørenssen et al., 1978).

Endorphin and corticotropin peptidergic systems also affect the activity of this group of limbic forebrain neurons. $\beta$-Endorphin, administered into the lateral ventricle, increases hippocampal acetylcholine (ACh) levels without changing the concentrations of this neurotransmitter in the cortex or striatum (Botticelli and Wurtman, 1979); given intraseptally, it causes a naltrexone-reversible decrease in the turnover of hippocampal ACh (Moroni et al., 1978). The opioid neuropeptide and adrenocorticotropin-1-14 $\left(\mathrm{ACTH}_{1-24}\right)$ increase and decrease, respectively, hippocampal ACh levels after intraventricular 
or intraseptal injection (Botticelli and Wurtman, 1981). Co-administration of endorphin and corticotropin blocks the effects of both on ACh concentrations in the hippocampal formation (Botticelli and Wurtman, 1980, 1981). When the neuropeptides are applied directly to the hippocampus, ACh levels remain unchanged (Botticelli and Wurtman, 1981). These observations suggest that the neuropeptides may act at the level of cholinergic cell bodies in the septal region to modulate the activity of septal cholinergic afferents terminating in Ammon's horn.

We now describe the ability of a variety of endorphin/ corticotropin neuropeptides, microadministered at varying doses into the lateral ventricle, the septal region, or the hippocampus, to affect ACh levels in the hippocampal formation. Parallel studies were conducted in which the neuropeptides were injected after acute unilateral transection of a major afferent cholinergic channel to the hippocampus (i.e., the fimbria/superior fornix). In addition, the effects of naloxone administration on peptideinduced changes in hippocampal ACh levels are described.

\section{Materials and Methods}

Animals. Male Sprague-Dawley rats (Charles River Breeding Laboratories, Wilmington, MA), each weighing 150 to $200 \mathrm{gm}$, were housed in groups of two or threc in suspended stainless steel wire cages at an ambient temperature of 23 to $24^{\circ} \mathrm{C}$ for 5 to $7 \mathrm{~d}$ before experimentation. The animals had free access to food (Purina Rat Chow, Ralston-Purina Co., St. Louis, $\mathrm{MO}$ ) and water and were exposed to light (Vita-Lite, $300 \mu \mathrm{W} / \mathrm{cm}^{2}$, Duro-Test Corp., North Bergen, NJ) daily between 7 AM and 7 PM.

Chemicals. $\beta$-Endorphin (synthesized by Dr. C. H. Li, Hormone Research Laboratory, University of California Medical Center, San Francisco, CA) was provided by the Psychopharmacology Research Branch, National Institute of Mental Health, Bethesda, MD. $\beta$-Lipotropin $(\beta$ $\mathrm{LPH})$ and $\beta$-melanotropin ( $\beta$-MSH) were gifts of Dr. C. $\mathrm{H}$. Li. $\mathrm{ACTH}_{1-39}, \mathrm{ACTH}_{1-24}, \mathrm{ACTH}_{4-10}$, and $\alpha$-melanotropin ( $\alpha$-MSI) were supplied by Organon Pharmaceuticals, Oss, The Netherlands. $\alpha$-Endorphin and $\gamma$-endorphin were purchased from Peninsula Laboratories, San Carlos, CA. Naloxone hydrochloride was a gift of Endo Laboratories, Garden City, NY. Acetylcholinesterase (acetylcholine acetylhydrolase, EC 3.1.1.7, 1000 units/ml, electric eel lyophilized powder) and choline kinase (choline phosphokinase, ATP:choline phosphotransferase, EC 2.7.1.32, 0.5 unit $/ \mathrm{ml}$ ) were purchased from Sigma Chemical Co., St. Louis, MO. $\left[\gamma_{-}{ }^{32} \mathrm{P}\right] \mathrm{ATP}$ (adenosine $5^{\prime}-\left[\gamma_{-}{ }^{32} \mathrm{P}\right]$ triphosphate, tetraethylammonium salt, $50 \%$ aqueous ethanol; specific activity, 10 to $30 \mathrm{Ci} / \mathrm{mmol}$ ) was obtained from Amersham Radiochemicals, Arlington Heights, IL. All other chemicals used were analytic grade and were purchased from either Eastman Organic Co., Rochester, NY or from Aldrich Chemical Co., Milwaukee, WI.

Microinjection procedures. For placements of cannulae, rats were anesthetized briefly with methohexital sodium (Brevital, Eli Lilly, Indianapolis, IN; $50 \mathrm{mg} / \mathrm{kg}$, $0.1 \mathrm{ml} / 100 \mathrm{gm}$ of body weight) and then stabilized in a small animal stereotaxic frame. A polyethylene tube (Clay Adams, Parsippany, NJ) was implanted into each rat's lateral ventricle $(2 \mathrm{~mm}$ lateral and $1 \mathrm{~mm}$ posterior to bregma and $3 \mathrm{~mm}$ ventral to the dural surface) $3 \mathrm{~d}$ before experimentation. Cannulae were kept in position with dental cement. All intraventricular injections (10 $\mu l$ over a 5-min period) were made, under visual guidance, using a microsyringe (Hamilton Co., Reno, NV) lowered through the polyethylene sleeve $3 \mathrm{~mm}$ ventral to the dural surface. Microadministration into the lateral ventricle was verified by visualizing the distribution of methylene blue throughout the cerebroventricular system.

For intraseptal injections, guide cannulae (28 gauge, Plastic Products Co., Roanoke, VA) were implanted stereotaxically into the septum (coordinates: AP 8.6, ML 0.0, DV $0.0,5.0 \mathrm{~mm}$ ventral to the dural surface) $5 \mathrm{~d}$ before study. All intraseptal injections were made using a microsyringe in a final volume of $1.0 \mu \mathrm{l}$ over a 10 -min period. Injection into the septum was verified by examining a 1:3 series of $40-\mu \mathrm{m}$ frozen frontal cryostat sections stained with thionin or cresyl echt violet and by schematic reconstruction drawings using the stereotaxic atlases of Konig and Klippel (1963) and Jacobowitz and Palkovits (1974). For intrahippocampal injections, cannulae were placed into the dorsal hippocampus (coordinates: AP 4.0, ML 2.0, DV 2.0) $3 \mathrm{~d}$ before experimentation. Peptides were administered into the hippocampus using a microsyringe in a final volume of $1.0 \mu \mathrm{l}$ over a 5 -min period. Histologic verification was made as described above.

Drug injections. Naloxone hydrochloride was dissolved in deionized distilled water and diluted to a concentration that allowed the studied dose $(1.0 \mathrm{mg} / \mathrm{kg}$, s.c. $)$ to be injected in a final volume of $0.1 \mathrm{ml} / 100 \mathrm{gm}$ of body weight. When naloxone was injected into the lateral ventricle, a dose of $100 \mu \mathrm{g}$ was used. The doses used refer to the drug salts.

Transection procedure. To separate the hippocampus from its cholinergic dorsal efferents, rats were anesthetized with methohexital sodium $(50 \mathrm{mg} / \mathrm{kg}, 0.1 \mathrm{ml} / 100$ gm of body weight) and then stabilized in a small animal stereotaxic frame. A scalp wound was made midline and the skin was reflected laterally. The fimbria/superior fornix was cut unilaterally using a No. 11 scalpel blade inserted vertically through a skull slot at a point $3.0 \mathrm{~mm}$ lateral to bregma to a point $1.0 \mathrm{~mm}$ lateral to lambda. The depth of the cut was $4.0 \mathrm{~mm}$ from the rostral to caudal aspects (Storm-Mathisen and Guldberg, 1974). Completeness of the transection was verified first by examination of a thionin- or cresyl echt violet-stained 1:5 series of $40-\mu \mathrm{m}$ frozen frontal cryostat sections and schematic reconstruction drawings and then by determining the time course for the decline in hippocampal ACh contents.

Radioenzymatic assay for determination of ACh content. Determination of ACh was based on the conversion of choline (Ch) to phosphorylcholine (PCh) in the presence of $\left[\gamma-{ }^{32} \mathrm{P}\right] \mathrm{ATP}$ and a partially purified choline kinase (Goldberg and McCaman, 1973). After skull-directed microwave irradiation $(2.0 \mathrm{sec})$, brains were removed and specimens of the dorsal hippocampus were dissected. Tissues were weighed, frozen on dry ice, and then placed in 1.5-ml centrifuge tubes (Sarstedt, Federal Republic of Germany). Samples were sonicated, using a Cell-Disruptor (Heat Systems-Ultrasonics Inc., Plainview, NY), in $1.0 \mathrm{ml}$ of protein-precipitating solution ( $15 \%$ formic acid/ acetone, v/v). Homogenates were centrifuged at 2000 
rpm for $20 \mathrm{~min}$ at $2^{\circ} \mathrm{C}$ in a Beckman TJ-6 centrifuge (Beckman Instruments, Spinco Division, Palo Alto, CA). The aqueous supernatant solutions were extracted individually with $300 \mu \mathrm{l}$ of tetraphenylboron/3-heptanone (5 $\mathrm{mg} / \mathrm{ml}$, Aldrich), mixed on a Vortex mixer, and centrifuged again at $2000 \mathrm{rpm}$ for $10 \mathrm{~min}$ at $2^{\circ} \mathrm{C}$. The resulting organic phase $(200 \mu \mathrm{l})$ was back-extracted with $300 \mu \mathrm{l}$ of $0.4 \mathrm{~N} \mathrm{HCl}$. After mixing and recentrifugation, the organic phase was aspirated and $100-\mu \mathrm{l}$ aliquots of the acid phase were transferred to $6 \times 50 \mathrm{~mm}$ culture tubes (Kimble, Toledo, $\mathrm{OH}$ ) and centrifuged to dryness using a Savant Speed-Vac Concentrator (Savant Instruments, Hicksville, NY).

After the lyophilisate was reconstituted in deionized distilled water, endogenous $\mathrm{Ch}$ was phosphorylated to unlabeled PCh in the presence of $0.1 \mathrm{M}$ ATP and choline kinase. ACh then was hydrolyzed by acetylcholinesterase and the resulting $\mathrm{Ch}$ was phosphorylated using $\left[\gamma^{32} \mathrm{P}\right\rfloor$ ATP as the substrate. After incubation at $30^{\circ} \mathrm{C}$ for 10 min, this reaction was quenched by the addition of 200 $\mu \mathrm{l}$ of ice cold deionized distilled water. Unreacted $\left[\gamma^{32} \mathrm{P}\right]$ ATP was removed by passing the mixture over $0.5 \times 5.0$ cm Dowex anion exchange columns (AG1-X8, 200 to 400 mesh, formate form; Bio-Rad Laboratories, Richmond, CA). $\left[\gamma^{32} \mathrm{P}\right\rfloor$ ATP was eluted with $2.0 \mathrm{ml}$ of $75 \mathrm{mM}$ ammonium formate, collected into polyethylene scintillation vials (Kimble) containing $15 \mathrm{ml}$ of Scintiverse (Fisher Scientific Co., Fair Lawn, NJ), and counted in a Beckman LS-7500 liquid scintillation spectrometer (Beckman Instruments, Irvine, CA). ACh content, expressed as nanomoles per gm, was determined by linear regression analysis and then by dividing the total nanomoles of ACh per sample by the respective tissue weights.

Statistical analyses. The significance of treatmentinduced differences in hippocampal $\mathrm{ACh}$ was determined by an analysis of variance (Wang 2200 series software, Wang Laboratories, Lowell, MA) followed by a posteriori multiple comparisons using Scheffe's method (Winer, 1971).

\section{Results}

Effects of intraventricular, intraseptal, or intrahippocampal neuropeptides on hippocampal ACh. Levels of hippocampal ACh remained unchanged after intraventricular administration of $\beta$-LPH, $\alpha$-endorphin, $\gamma$-endorphin, $\mathrm{ACTH}_{1-39}, \mathrm{ACTH}_{4-10}, \alpha-\mathrm{MSH}$, or $\beta$-MSH $(1,3,10$, or $30 \mu \mathrm{g}$ each). Over the same dose range, $\beta$-endorphin or $\mathrm{ACTH}_{1-24}$ increased or decreased, respectively, hippocampal ACh levels (Table I). Naloxone hydrochloride (1 $\mathrm{mg} / \mathrm{kg}$, s.c.), which alone had no effect of ACh concentrations, antagonized fully endorphin- or corticotropininduced changes in hippocampal ACh (Table II).

Microinjection of $\beta$-endorphin or $\mathrm{ACTH}_{1-24}(1.0 \mu \mathrm{g}$ each) into the septal region affected levels of hippocampal ACh as they did after intraventricular peptide injection but to a greater extent. $\beta$-Endorphin increased $\mathrm{ACh}$ content, while $\mathrm{ACTH}_{1-24}$ decreased levels of the neurotransmitter (Table III). Intraventricular naloxone administration $(100 \mu \mathrm{g})$, which alone failed to affect hippocampal ACh, blocked fully peptide-induced changes in ACh levels (Table III).

Administration of $\beta$-endorphin or $\mathrm{ACTH}_{1-24}(1,3,10$,
TABLE I

Effects of endorphin/corticotropin neuropeptides on hippocampal ACh

Peptides were injected into the lateral ventricle in a final volume of $10 \mu$ l over a 5 -min period. Rats were killed $30 \mathrm{~min}$ thereafter by a beam of microwave irradiation directed at the skull. Brains were removed and specimens of dorsal hippocampus were dissected. ACh was determined as described under "Materials and Methods." The values are expressed as the means \pm SFM. Data were analyzed by an analysis of variance followed by a posteriori multiple comparisons using Scheffe's method. All experimental groups contained five animals.

Hippocampal ACh

\begin{tabular}{ccccc}
\cline { 2 - 4 } Treatment & \multicolumn{4}{c}{ Peptide Dose $(\mu \mathrm{g} / \mathrm{brain})$} \\
\cline { 2 - 5 } & 1 & 3 & 10 & 30 \\
\hline \multicolumn{4}{c}{$\mathrm{nmol} / \mathrm{gm}$}
\end{tabular}

Vehicle

$37.9 \pm 2.1$

$\begin{array}{lllll}\beta \text {-Lipotropin } & 41.3 \pm 1.7 & 39.6 \pm 1.5 & 40.2 \pm 2.1 & 43.7 \pm 1.9 \\ \alpha \text {-Endorphin } & 36.9 \pm 2.3 & 42.1 \pm 1.6 & 40.3 \pm 1.8 & 38.7 \pm 3.0 \\ \beta \text {-Endorphin } & 39.3 \pm 1.1 & 45.0 \pm 1.9^{u} & 52.2 \pm 2.1^{b} & 57.3 \pm 1.9^{c} \\ \gamma \text {-Endorphin } & 40.0 \pm 2.0 & 41.3 \pm 2.1 & 40.1 \pm 1.3 & 36.8 \pm 2.1 \\ \text { ACTH }_{1-39} & 38.7 \pm 0.7 & 39.0 \pm 1.3 & 42.8 \pm 2.0 & 41.9 \pm 1.8 \\ \text { ACTH }_{1-24} & 37.6 \pm 0.9 & 34.3 \pm 1.1^{d} & 28.7 \pm 1.1^{e} & 23.4 \pm 1.0^{\prime} \\ \text { ACTH }_{4-10} & 40.1 \pm 2.1 & 38.3 \pm 0.9 & 43.2 \pm 2.0 & 41.0 \pm 1.0 \\ \alpha \text {-Melanotropin } & 36.5 \pm 1.5 & 38.9 \pm 1.3 & 40.2 \pm 2.3 & 44.0 \pm 1.5 \\ \beta \text {-Melanotropin } & 39.0 \pm 2.0 & 41.2 \pm 1.9 & 43.0 \pm 2.0 & 42.9 \pm 0.9\end{array}$

${ }^{a} p<0.05$ differs from vehicle-treated animals.

${ }^{b} p<0.01$ differs from vehicle-treated animals or from $\beta$-endorphin (3- $\mu \mathrm{g})$-treated animals.

${ }^{c} p<0.01$ differs from vehicle-treated animals or from $\beta$-endorphin (3- or 10- $\mu \mathrm{g})$-treated animals.

${ }^{d} p<0.1$ differs from vehicle-treated animals.

${ }^{e} p<0.05$ differs from vehicle-treated animals or from $\mathrm{ACTH}_{1-24}$ (3$\mu \mathrm{g})$-treated animals.

${ }^{f} p<0.05$ differs from vehicle-treated animals or from $\mathrm{ACTH}_{1-24}$ (3or $10-\mu \mathrm{g})$-treated animals.

or $30 \mu \mathrm{g}$ each) directly into the hippocampal formation did not change ACh levels in Ammon's horn (Table IV).

None of the treatments altered hippocampal choline levels (data not shown).

Effects of unilateral fimbrial transection on peptideinduced changes in hippocampal ACh. Unilateral transection of the fimbria/superior fornix resulted in a timerelated decrease in hippocampal ACh levels. Concentrations of the neurotransmitter did not change $1 \mathrm{hr}$ after transection; however, hippocampal ACh levels decreased to 72 and $26 \%$ of control values $1 \mathrm{~d}$ and 1 week, respectively, after deafferentation. ACh levels in the contralatcral intact hippocampus remained unaffected at all times tested (Table V). Fimbrial transection, performed $90 \mathrm{~min}$ before neuropeptide administration, blocked fully endorphin- or corticotropin-induced changes in hippocampal $\mathrm{ACh}$ after the neuropeptides were injected into either the lateral ventricle $(10 \mu \mathrm{g})$ or septal region $(1.0 \mu \mathrm{g})$ (Table VI).

\section{Discussion}

These data show that $\beta$-endorphin and $\mathrm{ACTH}_{1-24}$, injected into the lateral ventricle, produce opposite and dose-dependent changes in ACh levels within terminals of septohippocampal neurons: $\beta$-endorphin increases hip- 
pocampal ACh, while $\mathrm{ACTH}_{1-24}$ decreases levels of the neurotransmitter. When peptides are injected into the septum, hippocampal ACh changes similarly but to a greater extent. Direct application of either substance into Ammon's horn is, regardless of dose, without effect on hippocampal ACh. Fimbrial transection fully blocks both endorphin- and corticotropin-induced changes in hippocampal $\mathrm{ACh}$ after the neuropeptides are injected into either the lateral ventricle or the septal region. Naloxone, which, after subcutaneous or intraventricular injection, fails to change hippocampal ACh levels, antagonizes the change produced by both endorphin and corticotropin. These observations suggest that $\beta$-endorphin and $\mathrm{ACTH}_{1-24}$ may act at receptor sites on membranes of cell bodies in the septal region to modulate the activity of septal cholinergic afferents terminating in Ammon's horn.

The medial septal nucleus and the nucleus of the

\section{TABLE II}

Effects of intraventricular endorphin and corticotropin on hippocampal ACh: Antagonism by naloxone administration

Naloxone $(1 \mathrm{mg} / \mathrm{kg})$ was injected subcutaneously $5 \mathrm{~min}$ before $\beta$ endorphin or $\mathrm{ACTH}_{1-24}$ (10 $\mu \mathrm{g}$ each) was injected into the lateral ventricle. Rats were killed $30 \mathrm{~min}$ after peptide administration by focused microwave irradiation. The values are expressed as the means \pm SEM. Data were analyzed by an analysis of variance followed by $a$ posteriori multiple comparisons using Scheffe's method. All experimental groups contained five animals.

\begin{tabular}{lc}
\hline \multicolumn{1}{c}{ Treatment } & Hippocampal ACh \\
\hline & nmol/gm \\
Vehicle & $40.2 \pm 1.9$ \\
Naloxone & $37.2 \pm 1.1$ \\
$\beta$-Endorphin & $51.1 \pm 0.9^{\alpha}$ \\
ACTH $_{1-24}$ & $32.9 \pm 1.6^{b}$ \\
-Endorphin + naloxone $_{\text {ACTH }}$ + naloxone & $41.8 \pm 2.1^{c}$ \\
ACT $_{1-2}$ & $38.2 \pm 1.4^{d}$ \\
\hline
\end{tabular}

${ }^{a} p<0.005$ differs from vehicle-treated animals.

${ }^{b} p<0.01$ differs from vehicle-treated animals.

${ }^{c} p<0.001$ differs from peptide-treated animals.

${ }^{d} p<0.05$ differs from vehicle-treated animals.

TABLE III

Effects of intraseptal endorphin or corticotropin on hippocampal ACh: Antagonism by naloxone administration

Peptides (1.0 $\mu \mathrm{g}$ each) were injected into the septal region $30 \mathrm{~min}$ before killing. Naloxone $(100 \mu \mathrm{g})$ was injected into the lateral ventricle immediately before neuropeptide administration. Rats were killed by focused microwave irradiation. The values are expressed as the means \pm SEM. Data were analyzed by an analysis of variance followed by $a$ posteriori multiple comparisons using Scheffe's method. All experimental groups contained four animals.

\begin{tabular}{lc}
\hline \multicolumn{1}{c}{ Treatment } & Hippocampal ACh \\
\hline & $n m o l / g m$ \\
Vehicle & $36.2 \pm 2.2$ \\
Naloxone & $39.3 \pm 1.1$ \\
$\beta$-Endorphin & $57.2 \pm 1.4^{a}$ \\
ACTH $_{1-24}$ & $23.1 \pm 2.5^{b}$ \\
$\beta$-Endorphin + naloxone & $40.0 \pm 1.4^{c}$ \\
ACTH $_{1-24}+$ naloxone & $39.1 \pm 2.0^{d}$ \\
\hline
\end{tabular}

${ }^{a} p<0.001$ differs from vehicle-trealed animals.

${ }^{b} p<0.005$ differs from vehicle-treated animals.

${ }^{c} p<0.001$ differs from peptide-treated animals.

${ }^{d} p<0.005$ differs from peptide-treated animals.
TABBLE İV

Effects of intrahippocampal endorphin or corticotropin on hippocampal ACh

$\beta$-Endorphin or $\mathrm{ACTH}_{1-24}$ was microinjected into the dorsal hippocampus in a final volume of $1.0 \mu \mathrm{l}$ over a 5 -min period. Rats were killed $30 \mathrm{~min}$ later by microwave irradiation. The values represent the means \pm SEM. All experimental groups contained four animals.

\begin{tabular}{|c|c|c|c|c|}
\hline \multirow{3}{*}{ Treatment } & \multicolumn{4}{|c|}{ Hippocampal ACh } \\
\hline & \multicolumn{4}{|c|}{ Peptide Dose ( $\mu$ g/hippocampus) } \\
\hline & 1 & 3 & 10 & 30 \\
\hline & \multicolumn{4}{|c|}{$\mathrm{nmol} / \mathrm{gm}$} \\
\hline Vehicle & \multicolumn{4}{|c|}{$39.2 \pm 1.9$} \\
\hline$\beta$-Endorphin & $37.2 \pm 0.9$ & $41.2 \pm 1.1$ & $40.3 \pm 0.9$ & $41.0 \pm 1.4$ \\
\hline $\mathrm{ACTH}_{1-24}$ & $38.1 \pm 1.4$ & $40.4 \pm 2.3$ & $41.6 \pm 1.5$ & $36.5 \pm 0.8$ \\
\hline
\end{tabular}

TABLE V

Time course for change in hippocampal ACh after unilateral transection of the fimbria/superior fornix

Transection of the fimbria/superior fornix was performed as described under "Materials and Methods." Animals were killed by focused microwave irradiation $1 \mathrm{hr}, 1 \mathrm{~d}$, or 1 week after transection. Specimens of intact or transected hippocampi were dissected and their ACh content was determined. The values are expressed as the means \pm SEM. Data were analyzed by an analysis of variance followed by $a$ posteriori multiple comparisons using Scheffe's method. All experimental groups contained four animals.

\begin{tabular}{lccc}
\hline \multirow{2}{*}{ Hippocampus } & \multicolumn{3}{c}{ Hippocampal ACh } \\
\cline { 2 - 4 } & $1 \mathrm{hr}$ & \multicolumn{3}{c}{ Time after Transection } \\
\cline { 2 - 4 } & \multicolumn{3}{c}{$n$ dol/gm } \\
\hline \\
Intact, contralateral & $40.2 \pm 1.9$ & $38.7 \pm 2.1$ & $43.1 \pm 1.8$ \\
Deafferented & $38.9 \pm 2.1$ & $28.0 \pm 3.2^{a}$ & $10.1 \pm 1.9^{b}$ \\
\hline
\end{tabular}

${ }^{a} p<0.01$ differs from deafferented at $1 \mathrm{hr}$.

${ }^{b} p<0.001$ differs from deafferented at 1 day.

diagonal band contain the cells of origin of septohippocampal cholinergic neurons. Fibers project by way of the fimbria/superior fornix and enter the hippocampal formation at the level of the stratum oriens to synapse on basal dendrites of pyramidal cells in Ammon's horn, in the hilar portion of the dentate gyrus, the subiculum and parasubiculum, and the entorhinal cortex (Swanson, 1978). The septal region is also the recipient of the major hypothalamic efferents emanating from such diencephalic regions as the arcuate nucleus, an area within which opiomelenocortin perikarya are found in abundance (Watson et al., 1978a, b; Botticelli, 1980). In addition, hippocampal efferent channels synapse in the lateral septal area which, in turn, adjoins the medial septal nuclei (Swanson, 1978). The septohippocampal cholinergic neurons receive axodendritic and axosomatic synapses in the septal region and axoaxonic synapses in the hippocampus. Moroni et al. (1978) observed that intraseptally administered $\beta$-endorphin produces a naltrexone-reversible decrease in the turnover of hippocampal $\mathrm{ACh}$ without changing levels of the neurotransmitter. Corticotropin and $\alpha-\mathrm{MSH}$ were reported by Wood et al. (1979) to increase ACh turnover in Ammon's horn (without altering hippocampal $\mathrm{ACh}$ ) even after transection of the major afferents emanating from such areas as the 
TABLE VI

Effects of fimbrial transection on $\beta$-endorphin- or ACTH ${ }_{1-24}$-induced changes in hippocampal ACh

Fimbrial transection was performed $90 \mathrm{~min}$ before peptide administration into either the lateral ventricle ( $10 \mu \mathrm{g}$ given over a 5 -min period) or the septal region (1.0 $\mu \mathrm{g}$ given over a 10 -min period). Rats were killed $30 \mathrm{~min}$ later by focused microwave irradiation. 'The values are expressed as the means \pm SEM. Data were analyzed by an analysis of variance followed by a posteriori multiple comparisons using Scheffe's method. All experimental groups contained five animals.

\begin{tabular}{lcc}
\hline \multirow{2}{*}{ 'I'reatment } & \multicolumn{2}{c}{ Hippocampal ACh } \\
\cline { 2 - 3 } & Intact, Contralateral & Deafferented \\
\hline & $43.2 \pm 1.8$ & $41.1 \pm 2.0$ \\
Vehicle & $52.2 \pm 2.1^{a}$ & $37.8 \pm 1.4^{b}$ \\
$\begin{array}{l}\beta \text {-Endorphin (intraven- } \\
\text { tricular) }\end{array}$ & $57.9 \pm 1.1^{\mathrm{c}}$ & $43.1 \pm 2.4^{d}$ \\
$\begin{array}{l}\beta \text {-Endorphin (intrasep- } \\
\text { tal) }\end{array}$ & $35.1 \pm 0.9^{e}$ & $39.2 \pm 1.4^{f}$ \\
$\begin{array}{l}\text { ACTH } \\
\quad \text { ular) }\end{array}$ & $30.2 \pm 2.3^{g}$ & $40.3 \pm 0.7^{h}$ \\
ACTH $_{1-24}$ (intraventric- &
\end{tabular}

${ }^{a} p<0.01$ differs from vehicle-treated animals.

${ }^{b} p<0.001$ differs from intact, contralateral hippocampus.

${ }^{c} p<0.005$ differs from vehicle-treated animals.

${ }^{a} p<0.005$ differs from intact, contralateral hippocampus.

${ }^{e} p<0.05$ differs from vehicle-treated animals.

${ }^{f} p<0.05$ differs from intact, contralateral hippocampus.

${ }^{g} p<0.005$ differs from vehicle-treated animals.

${ }^{n} p<0.005$ differs from intact, contralateral hippocampus.

cingulum, entorhinal cortex, and fimbria/superior fornix. These latter findings were interpreted as suggesting a direct action of the neuropeptides on receptors in the hippocampus. Our observations that intraventricular or intraseptal, but not intrahippocampal, $\beta$-endorphin and $\mathrm{ACTH}_{1-24}$ produce significant changes in hippocampal $\mathrm{ACh}$ and that acute unilateral fimbrial transection blocks these changes suggest that endorphin and corticotropin neurons act primarily within the septum to influence the activity of septohippocampal cholinergic neurons.

An increase in $\mathrm{ACh}$ levels could reflect accelerated synthesis of the transmitter (e.g., after choline administration) or slowed release, perhaps due to decreased neuronal firing; similarly, a decrease in ACh levels could reflect slowed synthesis or enhanced ACh turnover. Since neither $\beta$-endorphin nor $\mathrm{ACTH}_{1-24}$ affected hippocampal choline levels, we interpret our findings as demonstrating slowed and accelerated ACh turnover, respectively, after peptide administration. This interpretation is consistent with some of the conclusions drawn by Moroni et al. (1978) and by Wood et al. (1979). We are unable to explain why these investigators failed to detect the changes that we observed on ACh levels.

That naloxone, which alone failed to affect hippocampal ACh levels, blocked both $\beta$-endorphin- and $\mathrm{ACTH}_{1-}$ ${ }_{24}$-induced changes in $\mathrm{ACh}$ concentrations implies that these neuropeptides may produce their effects by interacting with macromolecules containing allormorphic or common structural units located on membranes of cholinergic cell bodies in the septal region. This supposition is supported by the observations that $\mathrm{ACTH}_{1-24}$ can interact with opioid receptors (Terenius et al., 1975) and that corticotropin, unlike $\alpha$-MSH or $\beta$-MSH, causes a dose-dependent inhibition of $\left[{ }^{3} \mathrm{H}\right] \beta$-endorphin binding to rat brain membranes (Akil et al., 1980).

Studies on the post-translational processing of opiomelanocortin neuropeptides suggest that endorphin and corticotropin are derived from a common precursor protein molecule (Eipper and Mains, 1980). Moreover, these substances are distributed similarly throughout the brain: they are concentrated within a major cell group of the arcuate nucleus of the hypothalamus and project to such terminal fields as the anterior hypothalamus, the pons, the central grey matter, and the septal region (Bloom et al., 1979; Watson et al., 1978a, b). Nerve fibers immunoreactive to both endorphin and corticotropin surround the third ventricle, extend throughout the diencephalon and portions of the limbic forebrain, and descend into the central grey. No endorphin- or corticotropin-like immunoreactivity is detected in the hippocampus, cerebrum, or cerebellar cortices. $\beta$-Endorphin and $\mathrm{ACTH}_{1-24}$ sometimes can block each other's effects or produce effects opposite to one another (Jacquet, 1978; Simantov, 1979; Botticelli and Wurtman, 1980, 1981); perhaps some of the neurons that release them participate reciprocally in common multisynaptic systems.

Strategically interposed, the septum appears to govern neuronal associations among prominent structures of the mammalian central nervous system. The functional set of the septohippocampal system thus may be viewed as processing a wide variety of sensory, visceral, and associative information. By acting at the level of the septal region, endorphin/corticotropin neuropeptides may regulate the activity of a prominent set of cholinergic neurons within the limbic domain and participate rather broadly in the information-processing mechanisms and synaptic organization of the mammalian basal forebrain.

\section{References}

Akil, H., W. A. Hewlett, J. D. Barchas, and C. H. Li (1980) Binding of ${ }^{3} \mathrm{H}-\beta$-endorphin to rat brain membranes: Characterization of opiate properties and interaction with ACTH. Eur. J. Pharmacol. 64: 1-8.

Assaf, S. Y., and J. J. Miller (1977) Excitatory action of the mesolimbic dopamine system on septal neurons. Brain Res. 129: 353-360.

Bloom, F. E., J. Rossier, E. L. F. Battenberg, A. Bayon, E. French, S. J. Henriksen, G. R. Siggins, N. Ling, and R. Guillemin (1979) $\beta$-Endorphin: Cellular localization, elcctrophysiological and behavioral effects. In Endorphins in Men tal Health Research, E. Usdin, W. E. Bunney, Jr., and N. Kline, Eds., pp. 17-29, Oxford University Press, New York.

Botticelli, L. J. (1980) $\beta$-Endorphin regulates transsynaptically the activity of septo-hippocampal cholinergic neurons. Ph.D. dissertation, Massachusetts Institute of Technology, Cambridge, $\mathrm{MA}$.

Botticelli, L. J., and R. J. Wurtman (1979) $\beta$-Endorphin administration increases hippocampal acetylcholine levels. Life Sci. 24: 1799-1804.

Botticelli, L. J., and R. J. Wurtman (1980) Endorphin and corticotropin regulate the activity of septo-hippocampal cholinergic neurons. In Endogenous and Exogenous Opiate Agonists and Antagonists, E. Leong Way, ed., pp. 187-189, Pergamon Press, Elmsford, NY.

Botticelli, L. J., and R. J. Wurtman (1981) Corticotropin regulates transsynaptically the activity of septo-hippocampal cholinergic neurons. Nature 289: 75-76.

Cuello, A. C., and I. Kanazawa (1978) The distribution of 
substance $\mathrm{P}$ immunoreactive fibers in the rat central nervous system. J. Comp. Neurol. 178: 129-156.

DeFrance, J. F., H. Yoshihara, R. A. McCrea, and S. T. Kitai (1975) Pharmacology of the inhibition in the lateral septal region. Exp. Neurol. 48: 502-523.

Eipper, B. A., and R. E. Mains (1980) Structure and biosynthesis of proadrenocorticotropin/endorphin and related peptides. Endocr. Rev. 1: 1-27.

Goldberg, A. M., and R. E. McCaman (1973) The determination of picomole amounts of acetylcholine in mammalian brain. $\mathrm{J}$. Neurochem. 20: 1-8.

Jacobowitz, D. M., and M. Palkovits (1974) Topographic atlas of catecholamines and acetylcholinesterase-containing neurons in the rat brain. J. Comp. Neurol. 157: 13-28.

Jacquet, Y. F. (1978) Opiate effects after adrenocorticotropin or $\beta$-endorphin injection into the periaqueductal grey matter of rats. Science 201: 1032-1034.

Konig, J. F. R., and R. A. Klippel (1963) The Rat Brain. A Stereotaxic Atlas of the Forebrain and Lower Parts of the Brain Stem, Krieger, Huntington, NY.

Malthe-Sørenssen, D., D. L. Cheney, and E. Costa (1978) Modulation of acetylcholine metabolism in the hippocampal cholinergic pathway by intraseptally injected substance P. J. Pharmacol. Exp. Ther. 206: 21-28.

McLennan, H., and J. J. Miller (1974) $\gamma$-Aminobutyric acid and inhibition in the septal nuclei of the rat. J. Physiol. (Lond.) 237: 625-633.

Moore, R. Y. (1978) Catecholamine innervation of the basal forebrain. I. The septal area. J. Comp. Neurol. 177: 665-684.
Moroni, F., D. L. Cheney, and E. Costa (1978) The turnover rate of acetylcholine in brain nuclei of rats injected intraventricularly and intraseptally with alpha- and beta-endorphin. Neuropharmacology 17: 191-196.

Simantov, R. (1979) Glucocorticoids inhibit endorphin synthesis by pituitary cells. Nature 280: 684-685.

Storm-Mathisen, J., and H. C. Guldberg (1974) Serotonin and noradrenalin in the hippocampal region: Effect of transection of afferent pathways on endogenous levels, high-affinity uptake and some transmitter-related enzymes. J. Neurochem. 22: 793-803.

Swanson, L. W. (1978) 'The anatomic organization of septohippocampal projections. Ciba Found. Symp. 58: 25-43.

Terenius, L., G. H. Gispen, and D. deWied (1975) ACTH-like peptides and opiate receptors in the rat brain: Structureactivity studies. Eur. J. Pharmacol. 44: 395-398.

Watson, S. J., H. Akil, C. W. Richards, III, and J. D. Barchas (1978a) Evidence for two separate opiate peptide neuronal systems. Nature 275: 226-228.

Watson, S. J., C. W. Richards, III, and J. D. Barchas (1978b) Adrenocorticotropin in rat brain: Immunocytochemical localization in cells and axons. Science 200: 1180-1182.

Winer, B. (1971) Statistical Principles in Experimental Design, pp. 205-210, McGraw-Hill, New York.

Wood, P. L., D. L. Cheney, and E. Costa (1979) Modulation of the turnover rate of hippocampal acetylcholine by neuropeptides: Possible site of action of $\alpha$-melanocyte-stimulating hormone, adrenocorticotropic hormone and somatostatin. J. Pharmacol. Exp. Ther. 209: 97-103. 